\title{
膜面のリンクルに関する感度解析*1
}

\section{Sensitivity Analysis for Membrane Wrinkling}

\author{
秋田 剛*2 ·名 取 通 弘*3 \\ Takeshi AKITA and Michihiro NATORI
}

Key Words : Structural Analysis, Membrane Wrinkling, Sensitivity Analysis, Wrinkle Reduction Design

\begin{abstract}
A new sensitivity analysis method for membrane wrinkling is presented. The wrinkling phenomenon is modeled by the tension filed theory with a projection technique. In the technique, the total strain energy in wrinkled membranes is effectively decomposed into elastic energy and zero-strain energy parts using a projection matrix. The zero-strain energy part depends on only the zero-energy deformation caused by wrinkling, and is utilized for a quantifier of degree of membrane wrinkling at a material point. The wrinkle quantity of the discretized membrane element is obtained by the integral of the zero-strain energy over each element. The total wrinkle quantity of whole membrane is also obtained by the summation of the elemental wrinkle quantities. The sensitivity of the total wrinkle quantity is derived with respect to displacement vector and also design parameter. The latter is given by the semi-analytical differentiation method (SDM). The proposed sensitivity analysis method is applied to a shape design problem for wrinkle reduction of a square membrane to demonstrate its effectiveness.
\end{abstract}

1.は じめ に

近年，軽量で高収納性という特徵を持つ膜材が，大型宇 宙構造物の構成要素として大きな゙注目を集めている.一般 に膜材は，圧縮力に対してほとんど抵抗することが出来な いため, 圧縮力の作用により容易に局所座屈を起こしリン クルを生じる.リンクルの存在は, 構造の力学的な特性に 大きな影響を与え, また形状的にも本来の機能を損なう可 能性があるので, 膜面構造物の設計ではリンクルの生じる 領域を極力少なくするように設計することが重要である．

地上の膜面建築物では, 等張力曲面を目的関数とした形 状設計によって，リンクルを生じない膜面を実現させるこ とが多い1,2) . また宇宙構造物では, 主にソーラーセイルを 対象として, 膜面内の応力状態を張力状態に保つように膜 面の周辺にケーブルを設置し, リンクルを除去する構造設 計か提案されている ${ }^{3,4)}$.これらの膜面の構造設計は, 膜面 のすべての領域を張力状態とすることを目的としたもので あり, 理論的には膜面のリンクルを完全に除去することが できるが, 一方で, 設計の結果得られる膜面の形状は強く 限定されたものとなる.宇宙空間で用いられる膜面構造物 の形状は多樣であり，形状を限定されることは，一般に望 ましくない. また，谷の機能を考えた場合，ミッションに 影響を与える領域のリンクルを低減するように設計を行え ば十分であることが多く ${ }^{5)}$, ある程度のリンクルを許容し

\footnotetext{
*1 C 2006 日本航空宇宙学会

平成 18 年 7 月 27 日, 第 48 回構造強度に関する講演会にて講演

平成 18 年 8 月 2 日原稿受理

$* 2$ 大阪府立大学大学院

*3 宇宙航空研究開発機構宇宙科学研究本部
}

た上での構造設計を行うほうか現実的である . 任意形状の 膜面構造の設計は , 張力場理論に基づいた膜面モデルを用 いて行われることが多い6). 張力場理論では，部分的にリ ンクルを生じた状態での膜面の大域的な力学特性を求める ことができ，部材に作用する圧縮力など構造設計に必要と される一般的な諸量を定量的に評価することができる．同 時に張力場理論では, リンクルの生じる領域を求めること ができ, 光れらの領域をミッションに必要な領域から分離 させるように設計を行う7).ただし，張力場理論を使った 設計，特にリンクル領域に関する設計では，これまでの方 法ではリンクルの強弱やパラメータに対する感度を定量的 に扱うことができず, 多数の数值計算を含む直感的なパラ メータサーベイによる設計を行う必要があった 。

本論文では, 膜面のリンクルを対象とした感度解析法を 定式化し，膜面の設計に適用する．感度解析による設計は， パラメータサーベイによる設計と比較して，より低コスト で行うことができ，また，設計者の直感による判断ミスを 回避することができるという利点を有する．感度解析によ る設計を行うためには, 評価関数を定義し, 光の設計変数 に関する感度を算出する必要がある．本論文では，以下の 四つの過程を通して, 膜面のリンクルに関する評価関数を 定義し, 兴の感度を求める：(1) 張力場理論による膜面のリ ンクルのモデル化 , (2) 膜面の物質点におけるリンクル量の 定義, (3) 膜要素及び膜面全体におけるリンクル量の定義, (4) 有限要素法に基づいた非線形感度解析 . まず (1)では, 膜面のリンクルを張力場理論によりモデル化する . 特に射 影行列を用いたリンクルモデル8) を適用し , リンクルの形 成された膜面の変形を, 通常の弾性変形とエネルギを発生 
しない面内収縮変形に分解する．また，射影行列を用いて，

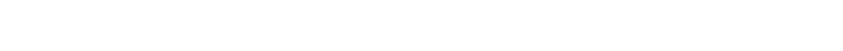
解する . 次に (2) では, 分解された歪みについて歪みエネ ルギの視点から考察を行い, 膜面の物質点におけるリンク ル量を表す関数を新たに定義する . 次に (3) では, 有限要 素法により離散化された膜面を考え, 要素ごとのリンクル 量を物質点におけるリンクル量の要素に対する積分量とし て定義する . また , 要素の重ね合わせにより，膜面全体のリ ンクル量を定義し，これを設計の評価関数とする.最後に (4) では, 評価関数の任意の設計変数に関する感度を, 半解 析微分法9)によって求める. 以上の項目について, 次章以 降でくわしく説明する. また, 数値計算例としてソーラセ イルのリンクル低減を目的とした形状設計問題を示し，本 論文で提案する設計法の有効性を示す.

\section{2. 張力場理論による膜面のリンクルモデル}

張力場理論に関してこれまでに多くの研究がなされてお り ${ }^{10)}$, 特に 1970 年代以降, 張力場理論を数值解析に適用す るための力学モデルか数多く提案されてきた . 剛性変化法 では, リンクルを生じた膜面の弾性行列を張力に直交する 方向の岡性を低下させるように修正し, 繰り返し計算により 張力場理論に適合する数值解を求めている吕 17)．また，リ ンクル状態にある膜面の変形勾配テンソルを張力場理論に 適合するように修正し，リンクルをモデル化する方法も考 案されている ${ }^{1828)}$.この方法は, 近年, 中篠ら ${ }^{27,28)}$ によっ て，ある種の岡性変化法に帰結されることが示されている． また，秋田ら ${ }^{8)}$ により中篠らの方法の線形代数的な解釈が なされ，射影行列を用いたリンクルモデルが提示されてい る . 応用数理的なリンクルのモデル化法として , "relaxed energy”を用いた方法がある29 35) .この方法では, 古典膜 理論の歪みエネルギ密度関数を "relaxed energy" に置き 換え, 張力場理論を数学的に厳密に古典膜理論に組み込ん でいる．ただし，"relaxed energy”に基づく定式化は高度 な数学的知識を要する . 以上の各種リンクルモデル間の関 係は，宮崎 ${ }^{36)}$ により詳細に論じられており，また，スラッ クを含めた一般的なリンクルモデルが提案され，"energymomentum” 法に基づく非線形動解析への定式化が行われ ている.

本論文では, 膜面のリンクルモデルとして, 秋田ら ${ }^{8)} に$ よる射影行列を用いたモデルを用いる．射影行列を用いた リンクルモデルは, 工学者に馴染み深い線形代数を基に, 古 典膜理論の範囲で定式化されており，取り扱いが容易であ る.また，後に示すように，射影行列の性質を用いて，膜 面の歪みエネルギ密度関数から, リンクルに起因するスカ ラ一関数を, 二次形式として明示的に求めることができる. 本章では, 後の感度解析の定式化のために, 射影行列を用 いたリンクルモデルを示す .

2.1 張力場理論の概要 はじめに, 張力場理論の基本的 な仮定について簡単に述べる. 張力場理論では, 膜面の曲 け剛性を零と仮定し, 膜面に圧縮応力が作用した際, リン クルの形成によって圧縮応力は完全に解放されるものと考

える(第 1 図 (a)) . このとき膜面の応力場は, 一方向の主 応力が正, もう一方向の主応力が零となる張力場でモデル 化される . また, リンクルの形成に伴う面外変形は, 張力 に直交する方向の面内収縮変形としてモデル化される（第 1 図 (b) ) .このとき, 面内収縮変形は主応力か零の方向へ の変形となるため, エネルギを発生しない特殊な変形モ一 ドとなる .これらの仮定から，張力場理論では膜面のリン クル現象を座屈解析を行うことなく平面問題として扱うこ とができる．ただし，通常の古典膜理論では，リンクルの 形成に伴う面内収縮变形を扱うことができず，特別な配慮 が必要となる.

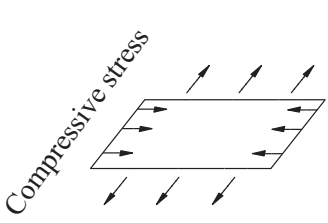

Tensile stress

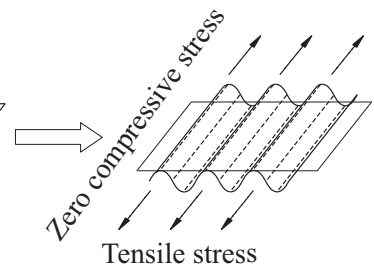

(a) Uniaxial tension state

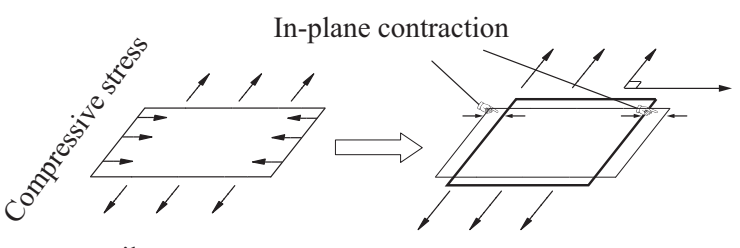

Tensile stress

(b) In-plane contraction

第 1 図 張力場理論の基本的な仮定

2.2 等方弾性膜の基礎式 次に, 本論文で用いる古典 膜理論における等方弾性膜の基礎式を示す. 平面応力状態 にある等方弾性膜の $x-y$ 座標系における応力, 歪み成分 を次式のように三次元ベクトルで表す．

$$
\begin{aligned}
\boldsymbol{\sigma} & =\left[\begin{array}{lll}
\sigma_{x} & \sigma_{y} & \tau_{x y}
\end{array}\right]^{T} \\
\boldsymbol{\epsilon} & =\left[\begin{array}{lll}
\varepsilon_{x} & \varepsilon_{y} & \gamma_{x y}
\end{array}\right]^{T}
\end{aligned}
$$

また，応力・歪み関係式を弾性行列 C を用いて

$$
\boldsymbol{\sigma}=\frac{E}{1-\nu^{2}}\left[\begin{array}{ccc}
1 & \nu & 0 \\
\nu & 1 & 0 \\
0 & 0 & (1-\nu) / 2
\end{array}\right] \boldsymbol{\epsilon}=\mathbf{C} \boldsymbol{\epsilon}
$$

と表す .ここで $E$ はヤング率， $\nu$ はポアソン比である.

いま，主軸座標系から角度 $\theta$ 回転した $x-y$ 座標系を考 えると, 応力, 歪み成分の主軸座標系から $x-y$ 座標系人 の成分変換式を, 以下のようにベクトル形式で表すことが できる .

$$
\begin{gathered}
\boldsymbol{\sigma}=\sigma_{1} \cdot \mathbf{n}_{1}+\sigma_{2} \cdot \mathbf{n}_{2} \\
\boldsymbol{\epsilon}=\varepsilon_{1} \cdot \mathbf{s}_{1}+\varepsilon_{2} \cdot \mathbf{s}_{2}
\end{gathered}
$$


ここで

$$
\begin{aligned}
& \mathbf{n}_{1}=\left[\begin{array}{lll}
\cos ^{2} \theta & \sin ^{2} \theta & \sin \theta \cos \theta
\end{array}\right]^{T} \\
& \mathbf{n}_{2}=\left[\begin{array}{lll}
\sin ^{2} \theta & \cos ^{2} \theta & -\sin \theta \cos \theta
\end{array}\right]^{T} \\
& \mathbf{s}_{1}=\left[\begin{array}{lll}
\cos ^{2} \theta & \sin ^{2} \theta & 2 \sin \theta \cos \theta
\end{array}\right]^{T} \\
& \mathbf{s}_{2}=\left[\begin{array}{lll}
\sin ^{2} \theta & \cos ^{2} \theta & -2 \sin \theta \cos \theta
\end{array}\right]^{T}
\end{aligned}
$$

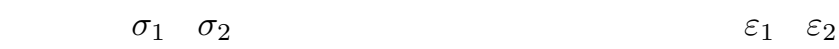
は光れ光れ最大・最小主歪み值を表す。

いま，次式で定義されるべクトル $\mathbf{n}_{3}$ を導入する .

$$
\mathbf{n}_{3} \equiv \mathbf{n}_{1} \times \mathbf{n}_{2}
$$

式 (10) と式 (3) との内積を取ると

$$
f(\theta)=\mathbf{n}_{3}^{T} \boldsymbol{\sigma}=\mathbf{n}_{3}^{T} \mathbf{C} \boldsymbol{\epsilon}=0
$$

のような $\theta$ と $\epsilon$ との関係式が得られる.上式は, 後に感度 評価式を導出する際に利用される。

2.3 射影行列を用いたリンクルモデル ここでは,物 理的な考察から, リンクルの形成を通常の弾性変形とエネ ルギを発生しない面内収縮変形の二つの変形プロセスの重 ね合わせとしてモデル化する .これらの変形プロセスから， リンクル状態にある膜面の全体歪みは, 純粋な弾性変形に 起因する部分と, リンクルに伴う面内収縮変形に起因する 部分に分解され，張力場理論特有の面内収縮変形の効果を 力学的な合理性をもってモデル化することができる．また， 分解された歪みのベクトル表現から, 膜面の全体歪みから 弾性部分を抽出する射影行列が導出され，射影行列による 歪みベクトルの分解表現が求められる .

いま，張力場状態にある膜面の主応力値を $\sigma_{1}$ とする . ま ず,第 2 図 (a) に示すように, 最初の変形プロセスとして , 張力 $\sigma_{1}$ による膜面の純粋な弾性変形を考える . このとき， 膜面は張力によって引張方向に, またポアソン効果によっ て収縮方向に変形する . このプロセスの变形の結果生じる 歪みは，純粋な弾性歪みとなる．次に，この状態から，第 2 図 (b) に示すように, 膜面がリンクルの発生に伴い張力 に直交する方向に収縮変形するプロセスを考える . 張力場 理論の仮定から，このプロセスの変形は, エネルギを発生 しない特別な変形モードとなる. この変形モードの結果生 じる歪みを, リンクルモード歪みと呼ぶことにする . 以上 より, リンクルを生じた膜面の全体歪みは, 弾性歪みとリ ンクルモード歪みに分解される.

次に, 弾性歪みとリンクルモード歪みをベクトル形式で 表し, 射影行列による歪みの分解表現を求める . まず，式 (4) より一軸の張力状態にある膜面の応力ベクトル $\sigma_{t}$ は

$$
\boldsymbol{\sigma}_{t}=\sigma_{1} \cdot \mathbf{n}_{1}+0 \cdot \mathbf{n}_{2}=\sigma_{1} \cdot \mathbf{n}_{1}
$$

と表される．いま， $\boldsymbol{\epsilon}_{w}$ をリンクルモード歪みベクトルとす ると， $\boldsymbol{\epsilon}_{w}$ がエネルギを発生しない条件は

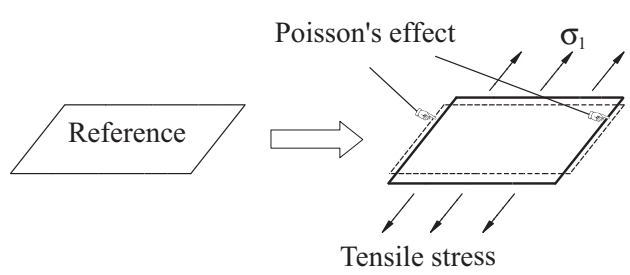

(a) Extension caused by uniaxial tensile stress

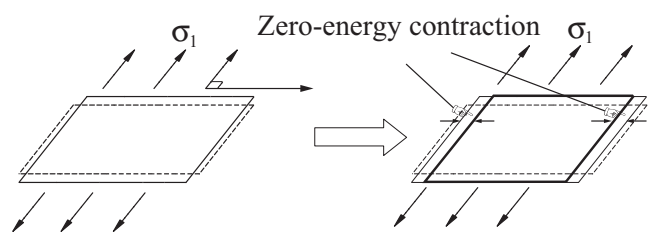

(b) Contraction caused by wrinkling 第2图 リンクルの形成プロセス

$$
\boldsymbol{\epsilon}_{w}^{T} \boldsymbol{\sigma}_{t}=0
$$

と表される.よって， $\mathbf{s}_{2}^{T} \mathbf{n}_{1}=0$ が成り立つことに注意す ると, 張力場理論の仮定からリンクル歪みベクトルを以下 のように表すことができる .

$$
\boldsymbol{\epsilon}_{w}=\varepsilon_{2 w} \cdot \mathbf{s}_{2}
$$

ここで $\varepsilon_{2 w}$ は, 非零のスカラー值である.式 (12) と式 (14) の内積を取ると

$$
\boldsymbol{\epsilon}_{w}^{T} \boldsymbol{\sigma}_{t}=\left(\varepsilon_{2 w} \sigma_{1}\right) \mathbf{s}_{2}^{T} \mathbf{n}_{1}=0
$$

となり，式 (14) が式 (13) の条件式を満足することがわか る. 次に, リンクル発生後の膜面の全体歪みベクトルを $\epsilon$ と置く.このとき, 弾性歪みべクトル $\epsilon_{e}$ は $\epsilon$ と $\epsilon_{w}$ の差分 として次式のように表される .

$$
\boldsymbol{\epsilon}_{e}=\boldsymbol{\epsilon}-\boldsymbol{\epsilon}_{w}=\boldsymbol{\epsilon}-\varepsilon_{2 w} \cdot \mathbf{s}_{2}
$$

弾性歪みは, 純粋な弾性変形の結果生じたものと考えられ るので, $\sigma_{t}$ と $\epsilon_{e}$ の間には次式のような古典膜理論に従っ た応力歪み関係が成り立つ。

$$
\boldsymbol{\sigma}_{t}=\mathbf{C} \boldsymbol{\epsilon}_{e}=\mathbf{C}\left(\boldsymbol{\epsilon}-\varepsilon_{2 w} \cdot \mathbf{s}_{2}\right)
$$

式 (14) と式 (17) を式 (15) に代入して整理すると

$$
\varepsilon_{2 w}=\frac{\mathbf{s}_{2}^{T} \mathbf{C} \boldsymbol{\epsilon}}{\mathbf{s}_{2}^{T} \mathbf{C} \mathbf{s}_{2}}
$$

を得る . 最後に式 (18) を式 (14) と式 (16) に代入すると次 式のように弾性歪みとリンクル歪みのベクトル形式が得ら れる。

$$
\begin{aligned}
\boldsymbol{\epsilon}_{w} & =\left(\mathbf{s}_{2}^{T} \mathbf{C} \boldsymbol{\epsilon}\right) /\left(\mathbf{s}_{2}^{T} \mathbf{C s}_{2}\right) \cdot \mathbf{s}_{2}=\mathbf{Q} \boldsymbol{\epsilon} \\
\boldsymbol{\epsilon}_{e} & =\boldsymbol{\epsilon}-\left(\mathbf{s}_{2}^{T} \mathbf{C} \boldsymbol{\epsilon}\right) /\left(\mathbf{s}_{2}^{T} \mathbf{C s}_{2}\right) \cdot \mathbf{s}_{2}=\mathbf{P} \boldsymbol{\epsilon}
\end{aligned}
$$

ここで $\mathbf{P}, \mathbf{Q}$ は $\mathbf{I}$ を $3 \times 3$ の単位行列として 


$$
\begin{aligned}
\mathbf{Q} & =\frac{\mathbf{s}_{2} \mathbf{s}_{2}^{T} \mathbf{C}}{\mathbf{s}_{2}^{T} \mathbf{C \mathbf { s } _ { 2 }}} \\
\mathbf{P} & =\mathbf{I}-\mathbf{Q}
\end{aligned}
$$

として定義された射影行列であり，以下の関係式を満たす．

$$
\begin{aligned}
\mathbf{Q}^{2} & =\frac{\left(\mathbf{s}_{2}^{T} \mathbf{C s}_{2}\right) \cdot \mathbf{s}_{2} \mathbf{s}_{2}^{T} \mathbf{C}}{\left(\mathbf{s}_{2}^{T} \mathbf{C s}_{2}\right) \cdot\left(\mathbf{s}_{2}^{T} \mathbf{C} \mathbf{s}_{2}\right)}=\mathbf{Q} \\
\mathbf{C Q} & =\frac{\mathbf{C s}_{2} \mathbf{s}_{2}^{T} \mathbf{C}}{\mathbf{s}_{2}^{T} \mathbf{C} \mathbf{s}_{2}}=(\mathbf{C Q})^{T} \\
\mathbf{P}^{2} & =\mathbf{I}-2 \mathbf{Q}+\mathbf{Q}^{2}=\mathbf{I}-\mathbf{Q}=\mathbf{P} \\
\mathbf{C P} & =\mathbf{C}-\mathbf{C Q}=(\mathbf{C}-\mathbf{C Q})^{T}=(\mathbf{C P})^{T}
\end{aligned}
$$

3. リンクルに関する評価関数とその感度

前章で示したように，リンクルを生じた膜面の全体歪み ベクトルは, 射影行列を用いて弾性歪みベクトルとリンク ルモード歪みベクトルに分解される .このうち, リンクル モード歪みベクトルは, リンクルに伴う幾何学的な収縮変 形を表しており, リンクルによる膜面の収縮量に依存した 量となる .よって, リンクルモード歪みベクトルを膜面の リンクルの度合いを表す評価関数として採用することが考 えられるが, ベクトル量を关のまま評価関数に用いること は, 感度解析の定式化上，あまり望ましくない，本章では， 歪みエネルギの視点から, リンクルモード歪みベクトルを 用いた取り扱いが容易な新たなスカラー関数を定義し，こ のスカラー関数を, 膜面の物質点におけるリンクルを表す 関数として用いる.また, 有限要素により離散化された膜 面に対して, 膜要素と膜面全体のリンクル量を表す評価関 数を定義し，光の感度評価式を求める.

3.1 膜面の物質点におけるリンクル量 いま, リンク ルを生じた膜面の歪みエネルギ密度関数 $\phi$ を考える. 前章 の考察から膜面の弾性変形は, 弾性歪みべクトル $\epsilon_{e}$ により 表されるので, $\phi$ は $\epsilon_{e}$ を用いて次式のように表すことがで きる .

$$
\phi=\frac{1}{2} \epsilon_{e}^{T} \mathbf{C} \epsilon_{e}
$$

ここで, 式 (27) に式 (20) を代入し，式 (25)，(26) を考慮 すると

$$
\phi=\frac{1}{2} \boldsymbol{\epsilon}^{T} \mathbf{P}^{T} \mathbf{C P} \boldsymbol{\epsilon}=\frac{1}{2} \boldsymbol{\epsilon}^{T} \mathbf{C P} \boldsymbol{\epsilon}
$$

を得る .さらに式 (28) に式 (22) を代入し，式 (23)，(24)， (19) を考慮すると，次式を得る .

$$
\phi=\frac{1}{2} \boldsymbol{\epsilon}^{T} \mathbf{C}(\mathbf{I}-\mathbf{Q}) \boldsymbol{\epsilon}=\phi_{p}-\phi_{w}
$$

ここで

$$
\begin{aligned}
\phi_{p} & =\frac{1}{2} \boldsymbol{\epsilon}^{T} \mathbf{C} \boldsymbol{\epsilon} \\
\phi_{w} & =\frac{1}{2} \boldsymbol{\epsilon}_{w}^{T} \mathbf{C} \boldsymbol{\epsilon}_{w}
\end{aligned}
$$

である . 式 (30) から , $\phi_{p}$ は通常の古典膜理論の歪みエネル ギ密度関数の定義式と一致する . また，式 $(31)$ から， $\phi_{w}$ は リンクルモード歪みベクトル $\epsilon_{w}$ に依存したスカラー関数， つまりリンクルによる膜面の収縮量に依存したスカラー関 数となる. 行列 $\mathbf{C}$ の正定值対称性から，このスカラ一関数 は非負の值を取る .式 (29) より, リンクルを生じた膜面の 歪みエネルギ密度関数は, 古典膜理論の歪みエネルギ密度 関数 $\phi_{p}$ から，非負関数 $\phi_{w}$ を差し引いた形で求められる このとき，非負関数 $\phi_{w}$ は, $\phi_{p}$ の $\phi$ に対する, リンクル が生じたことによる, ある種のエネルギーの過剰分を表し ており， $\phi_{w}$ の值が小さいほど膜面に生じたリンクルの強 度か弱い状態になると考えられる . 仮に $\phi_{w}=0$ とすると， $\boldsymbol{\epsilon}_{w}=\mathbf{0}$ ，つまり膜面にリンクルが存在しない状態となり， このとき $\phi_{p}$ は $\phi$ と一致し, 膜面の歪みエネルギ密度関数 を表す . 本論文では, 関数 $\phi_{w}$ を膜面の物質点におけるリ ンクル量を定量的に表す関数と考え, 以降で $\phi_{w}$ に基づい た感度評価式を導出する。

3.2 膜要素および膜面全体におけるリンクル量 前節 で定義した膜面の物質点におけるリンクル量を用いて, 膜 要素およひ膜面全体のリンクル量を定義する . いま , 有限 要素により離散化された膜面を考える．このとき， $k$ 番目 の膜要素のリンクル量を次式により定義する .

$$
U_{w}^{k} \equiv \int_{V_{e}} \phi_{w}\left(r_{1}, r_{2}\right) \mathrm{d} V
$$

ここで $V_{e}$ は変形前の膜要素の体積を表し,$r_{i}$ は膜要素の 埋め込み座標を表す . また膜面全体のリンクル量を次式に より定義する。

$$
U_{w} \equiv \sum_{k=1}^{N_{e}} w^{k} U_{w}^{k}
$$

ここで $N_{e}$ は膜要素の総数を表す．また， $w^{k}$ は要素 $k に$ 対する重み係数を表し, 膜面構造物のミッションに応じて， リンクルが生じてもミッションに影響を与えない要素の重 みを零にするなど, 設計要求に従って適切に設定されるも のとする .

3.3 リンクル量の感度 本節では, まず物質点におけ るリンクル量の歪みに対する感度を求め, 次に膜要素にお けるリンクル量の変位に対する感度を求める . 最後に, 膜 面全体におけるリンクル量の変位に対する感度を求め, 半 解析微分法により, 膜面全体のリンクル量の任意の設計変 数に対する感度評価式を求める.

3.3.1 物質点におけるリンクル量の感度 式 (31) に式 (19) を代入し，式 (23)，(24) を考慮すると，物質点におけ るリンクル量 $\phi_{w}$ を次式のように書き換えることができる .

$$
\phi_{w}=\frac{1}{2} \boldsymbol{\epsilon}^{T} \mathbf{Q}^{T} \mathbf{C Q} \boldsymbol{\epsilon}=\frac{1}{2} \boldsymbol{\epsilon}^{T} \mathbf{C Q} \boldsymbol{\epsilon}
$$

ここで式 (34) の両辺の変分を取り, 式 $(24)$ を考慮すると

$$
\delta \phi_{w}=\delta \boldsymbol{\epsilon}^{T} \mathbf{C Q} \boldsymbol{\epsilon}+\frac{1}{2} \boldsymbol{\epsilon}^{T} \mathbf{C} \delta \mathbf{Q} \boldsymbol{\epsilon}
$$


を得る.いま, 上式の右辺第二項を具体的に表すことを考 える . 式 (21) から行列 Q の変分は次式のように表される .

$$
\delta \mathbf{Q}=\frac{2\left(1-\nu^{2}\right)}{E}\left(\mathbf{n}_{3} \mathbf{s}_{2}^{T} \mathbf{C}+\mathbf{s}_{2} \mathbf{n}_{3}^{T} \mathbf{C}\right) \delta \theta
$$

ここで上式を導く際，以下の関係式を用いた .

$$
\mathbf{s}_{2}^{T} \mathbf{C s}_{2}=E /\left(1-\nu^{2}\right)=\text { const., } \delta \mathbf{s}_{2}=-2 \mathbf{n}_{3} \delta \theta
$$

式 (36) を式 (35) の右辺第二項に代入し，式 (11) に表され る関係式 $f(\theta)=\mathbf{n}_{3}^{T} \mathbf{C} \boldsymbol{\epsilon}=0$ を考慮すると

$$
\boldsymbol{\epsilon}^{T} \mathbf{C} \delta \mathbf{Q} \boldsymbol{\epsilon}=0
$$

を得る .よって式 (37) を式 (35) に代入すると, 関数 $\phi_{w}$ の 歪みベクトル $\epsilon$ に対する感度を

$$
\frac{\partial \phi_{w}}{\partial \boldsymbol{\epsilon}}=\mathbf{C Q} \boldsymbol{\epsilon}
$$

\section{として求められる .}

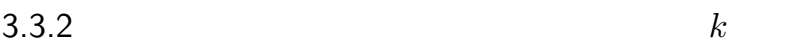
の膜要素における節点変位ベクトルを $\mathbf{u}_{e}^{k}$ とする . このと き, 式 (32) より膜要素におけるリンクル量 $U_{w}^{k}$ の $\mathbf{u}_{e}^{k}$ に対 する感度は，

$$
\frac{\partial U_{w}^{k}}{\partial \mathbf{u}_{e}^{k}}=\int_{V_{e}} \mathbf{B}_{L}^{k^{T}} \frac{\partial \phi_{w}}{\partial \boldsymbol{\epsilon}} d V
$$

と表される.ここで

$$
\mathbf{B}_{L}^{k}=\frac{\partial \boldsymbol{\epsilon}}{\partial \mathbf{u}_{e}^{k}}
$$

は，通常の歪み・変位関係を表す行列である.式 (38)を (39) に代入すると

$$
\frac{\partial U_{w}^{k}}{\partial \mathbf{u}_{e}^{k}}=\int_{V_{e}} \mathbf{B}_{L}^{k^{T}} \mathbf{C Q} \boldsymbol{\epsilon} \mathbf{d V}
$$

を得る。

3.3.3 膜面全体におけるリンクル量の感度 有限要素に より離散化された膜面の全体節点べクトルを $\mathbf{u}_{g}$ とする .こ のとき, 式 (33), (41) より膜面全体におけるリンクル量 $U_{w}$ の $\mathbf{u}_{g}$ に対する感度は

$$
\frac{\partial U_{w}}{\partial \mathbf{u}_{g}}=\sum_{k=1}^{N_{e}} w^{k} \mathbf{L}^{k^{T}} \frac{\partial U_{w}^{k}}{\partial \mathbf{u}_{e}}
$$

と表される．ここで $\mathbf{L}^{k}$ は次式で定義される結合ブーリア ン行列である。

$$
\mathbf{u}_{e}^{k}=\mathbf{L}^{k} \mathbf{u}_{g}
$$

次に $U_{w}$ の任意の設計変数 $b_{j}$ に関する感度を, 半解析微 分法 ${ }^{9)}$ により求める.いま, $\mathrm{q}$ を内力べクトル, f を外力 ベクトルとすると, 非線形有限要素法における力の釣り合 い式は

$$
\mathbf{q}\left(\mathbf{u}_{g}\left(b_{j}\right), b_{j}\right)=\mathbf{f}
$$

と表される.上式に対し, 設計変数 $b_{j}$ の変分を考えると,

$$
\frac{\partial \mathbf{q}}{\partial \mathbf{u}_{g}} \delta \mathbf{u}_{g}+\frac{\partial \mathbf{q}}{\partial b_{j}} \delta b_{j}=\mathbf{0}
$$

を得る . 式 (45) より $\mathbf{u}_{g}$ の $b_{j}$ に対する感度は次式で与え られる。

$$
\frac{\partial \mathbf{u}_{g}}{\partial b_{j}}=-\mathbf{K}^{-1} \frac{\partial \mathbf{q}}{\partial b_{j}}
$$

ここで

$$
\mathbf{K}=\frac{\partial \mathbf{q}}{\partial \mathbf{u}_{g}}
$$

は接線剛性行列である.式 (46) において, q の $b_{j}$ に対す る感度を求める必要があるが, これを解析的に求めること は一般に困難である. 半解析微分法では, q の感度を次式 に示すような数值差分に置き換えて評価する.

$$
\frac{\partial \mathbf{q}}{\partial b_{j}} \simeq \frac{\Delta \mathbf{q}}{\Delta b_{j}}
$$

ここで $\Delta b_{j}$ は, 設計変数の微小な摂動量であり，数值的に 与えられる．また， $\Delta \mathbf{q}$ は設計変数の捸動に対する内力べク トルの微小変化量を表す.以上より，式 (42), (46)，(48) から $U_{w}$ の設計変数に対する感度評価式が

$$
\frac{\partial U_{w}}{\partial b_{j}}=\frac{\partial U_{w}}{\partial \mathbf{u}_{g}} \frac{\partial \mathbf{u}_{g}}{\partial b_{j}} \simeq\left(-\mathbf{K}^{-1} \frac{\Delta \mathbf{q}}{\Delta b_{j}}\right)^{T} \frac{\partial U_{w}}{\partial \mathbf{u}_{g}}
$$

として求められる .

$$
\text { 4. ソーラーセイルの形状設計問題 }
$$

本章では, ソーラーセイルのリンクル低減を目的とした 形状設計問題に , 本論文で提案するリンクルに関する感度 解析を適用し，光の有効性を示す。

4.1 解析モデル 解析モデルとしては, 第 3 図 (a) に 示すような, 対角線長が $2 a$ である正方形膜を考える . 膜面 は，四頂点の強制変位 $u$ により張力を与えられ，このとき， 膜面の頂点と辺の周辺に大きなリンクルを生じる ${ }^{37)}$. 本モ デルは，もっとも基本的なタイプのソーラーセイルを表す． 本モデルに対し，第 3 図 (b) に示すような，対称性を考慮 した設計モデルを考え，形状設計によるリンクルの低減を 試みる. 第 3 図 (b) において, 三角形の斜辺上の点から， 底辺と直角の頂点への距離 $d_{1}, d_{2}$ を設計変数とし, 斜辺の 形状を変化させる．ただし，斜辺の形状は斜辺の垂直二等 分線に対して対称に設定される.

感度解析のための評価関数は次式により定義される。

$$
\begin{aligned}
& U_{w}(\mathbf{b}) \\
& \mathbf{b}=\left[\begin{array}{ll}
b_{1} & b_{2}
\end{array}\right]^{T}=\left[\begin{array}{ll}
d_{1} & d_{2}
\end{array}\right]^{T}
\end{aligned}
$$

ここで $U_{w}(\mathbf{b})$ は式 (33) で定義される膜面全体のリンクル 


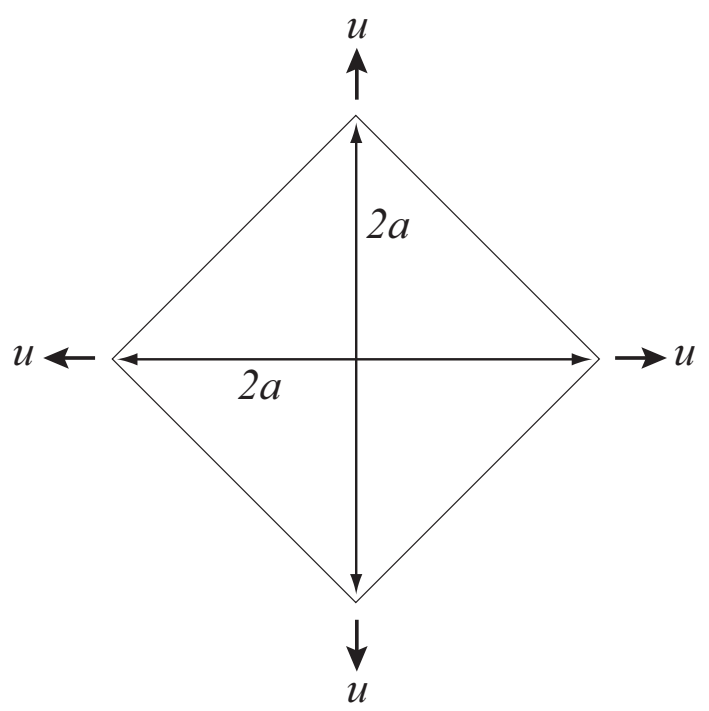

(a) Square membrane

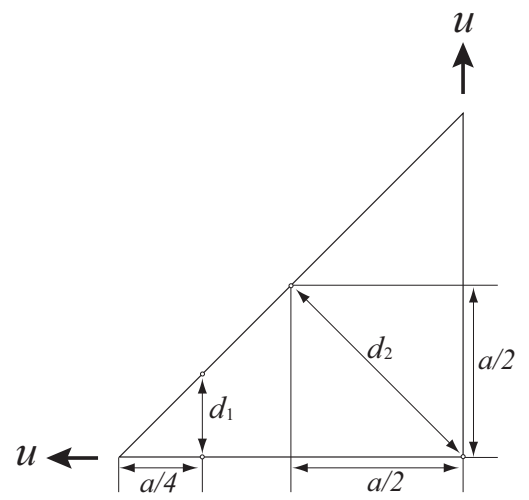

(b) Design model

第 3 図形状設計問題の設計モデル

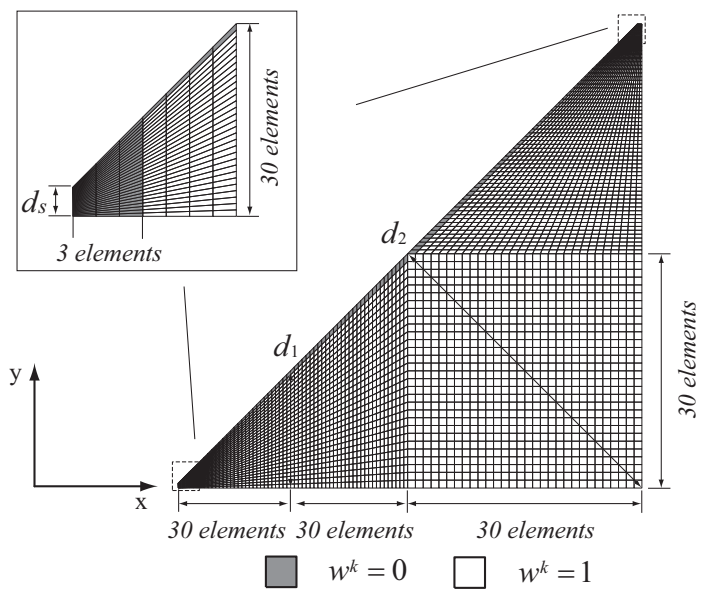

第 4 図 有限要素メッシュ
図に示す . 膜面の有限要素解析法としては, Total Lagrange 法に基づいた射影行列によるリンクル解析法を用いる8). 膜 面の底辺の長さは $a=1.0 \mathrm{~m}$ とし, 膜厚を $t=50 \mu \mathrm{m}$, ポ アソン比を $\nu=0.34$, ヤング率を $E=2.96 \mathrm{GPa}$ とする. 膜面は 4500 個の四節点アイソパラメトリック要素て離散 化され, 直角三角形の右辺上の節点については $x$ 方向に拘 束を，底辺上の節点については $y$ 方向に拘束を与える．ま た，鋭角の頂点については $d s=10 \mathrm{~mm}$ として面取りを行 い, 面取り線上の節点に対して $d s=10 \mathrm{~mm}$ の強制変位を 与える. 要素ごとの重み関数については, 斜辺上の要素及 び鋭角の頂点の周辺要素では, ソーラーセイルのミッショ ンにはほとんど影響を与えないので， $w_{k}=0$ とする. 光 れ以外の要素では $w_{k}=1$ とする.

4.2 感度評価式の検証 前章で述べたように, 半解析 微分法を用いた感度評価式 (49) では, 内力ベクトル q の 感度を数值差分により求める必要がある．本論文では，差 分法として次式に示される中心差分法を用いる .

$$
\begin{aligned}
\frac{\partial \mathbf{q}}{\partial b_{j}} & \simeq \frac{\mathbf{q}\left(b_{j}+\Delta b_{j}\right)-\mathbf{q}\left(b_{j}-\Delta b_{j}\right)}{2 \Delta b_{j}} \\
\Delta b_{j} & =\beta \cdot b_{j}
\end{aligned}
$$

ここで $\beta$ は設計変数に捸動を与えるための微小な值である .

感度評価式の妥当性を検証するために，半解析微分法を 用いて式 (49)，(52) から求められる感度と，次式に示され る有限差分法によって求めらる感度との比較を行う．

$$
\frac{\partial U_{w}}{\partial b_{j}} \simeq \frac{U_{w}\left(b_{j}+\Delta b_{j}\right)-U_{w}\left(b_{j}-\Delta b_{j}\right)}{2 \Delta b_{j}}
$$

有限差分法は, 一般に非常に大きな計算コストを要するが， 解析的な感度評価式を用いずに簡便に感度を求められ，解 析的な感度評価式の妥当性の確認に利用されることが多い．

第 1 表に $\beta$ の值を $\beta=10^{-5} \sim 10^{-7}$ の範囲て変化させた ときの，初期状態 (斜辺が直線の状態) における，乥れ光れの 方法による感度值を示す.ただし，感度値は $\partial U_{w} / \partial d_{1}=1$ として正規化されている．表より，両方法で計算した感度 值は, 小数点二桁目まで良く一致しており, 半解析微分法 を用いた感度評価式の妥当性を確認できる。

第 1 表 半解析微分法と直接差分法の比較

\begin{tabular}{|c|c|c|c|}
\hline$\beta$ & 感度の計算方法 & $\partial U_{w} / \partial d_{1}$ & $\partial U_{w} / \partial d_{2}$ \\
\hline $10^{-5}$ & 半解析微分法 & 1.0000 & -0.1116 \\
\hline $10^{-5}$ & 有限差分法 & 1.0000 & -0.1102 \\
\hline $10^{-6}$ & 半解析微分法 & 1.0000 & -0.1116 \\
\hline $10^{-6}$ & 有限差分法 & 1.0000 & -0.1103 \\
\hline $10^{-7}$ & 半解析微分法 & 1.0000 & -0.1116 \\
\hline $10^{-7}$ & 有限差分法 & 1.0000 & -0.1103 \\
\hline
\end{tabular}

4.3 感度解析の形状設計問題への適用 ソーラーセイ ルの形状設計問題では, リンクル量のみならず, 膜面の面 積も設計の要素として重要である場合も考えられる . 本例 題では, 膜面の面積に制約を与えるペナルティ関数を，目 
的関数に組み込む． 形状設計問題の目的関数は, 以下のよ うに与えられる。

$$
\varphi(\mathbf{b})=U_{w}(\mathbf{b})+r \cdot U_{s}(\mathbf{b})
$$

ここで, $U_{s}(\mathbf{b})$ は膜面の面積の制約条件に相当するペナル ティ関数， $r$ は重み係数であり，重みの值が大きくなるほ ど，面積の制約条件が強くなる ${ }^{38)}$. 本例題では, $r=10^{3}$ とする.この目的関数に対し，以下の最小化問題を設定し， 形状設計を行う .

$\min \varphi(\mathbf{b})$

本例題では, 最小化問題の解法として, 最急降下法を適用す る.最急降下法では, 次式に従って設計変数を逐次更新し， 評価関数を減少させる新たな設計変数べクトルを求める.

$$
\begin{aligned}
& { }^{(i)} \mathbf{b}_{k+1}={ }^{(i)} \mathbf{b}_{k}-\left.s \cdot \frac{d \varphi}{d \mathbf{b}}\right|_{\mathbf{b}={ }^{(i)} \mathbf{b}_{1}} \\
& { }^{(i+1)} \mathbf{b}_{1}={ }^{(i)} \mathbf{b}_{n l}
\end{aligned}
$$

ここで $i$ は最急降下法の反復ステップ,$k$ は直線探索の反復 ステップ, $n l$ は直線探索の収束時の反復ステップ数,$s$ は 微小増分量である.膜面の面積に関する評価関数は, ${ }^{(i)} S_{k}$ を ${ }^{(i)} \mathbf{b}_{k}$ により計算された膜面の面積， $\gamma$ を面積の拘束条 件を決定するための係数として以下のように定義される .

$$
U_{s}\left({ }^{(i)} \mathbf{b}_{k}\right)=\min \left[0,\left({ }^{(i)} S_{k}-\gamma^{(1)} S_{1}\right)\right]^{2}
$$

本例題では， $\gamma=0.9$, つまり設計後の面積が , 初期状態の 面積の 9 割以上になるような拘束条件を設定する.式 (57) の右辺第二項の勾配ベクトルは, 次式のように膜面全体の リンクル量の感度及び面積の感度を用いて表され, 最急降 下法の反復ごとに計算される .

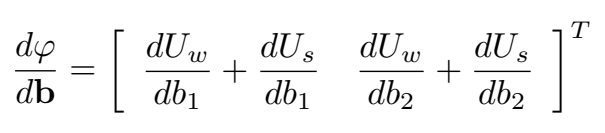

本例題では, 直線探索のための微小増分量の値を $s=10^{-3}$, 半解析微分法に用いる微小増分量の值を $\beta=10^{-5}$ とする. 直線探索は, 次式の判定基準が満たされるとき $k=n l$ と して反復計算を終了する .

$$
\varphi\left({ }^{(i)} \mathbf{b}_{k+1}\right)-\varphi\left({ }^{(i)} \mathbf{b}_{k}\right) \geq \alpha_{1}
$$

同樣に, 最急降下法は, 次式の判定基準か満たされるとき 反復計算を終了する .

$$
\varphi\left({ }^{(i+1)} \mathbf{b}_{n l}\right)-\varphi\left({ }^{(i)} \mathbf{b}_{n l}\right) \geq \alpha_{2}
$$

本例題では， $\alpha_{1}=\alpha_{2}=10^{-5}$ と設定する.

第 5 図に形状設計問題の解析手順を示す.まず設計変数 の初期値を設定し, 膜面の形状を決定する . 次に , 有限要 素解析により膜面の釣り合い形状を求め, 釣り合い形状に おける目的関数 $\varphi$ の值を計算する. 直線探索のステップ数 $k$ が 1 の場合は，式 (60)により感度を計算し，式 (57) に 従って設計变数を更新して, 直線探索を続ける. 直線探索 のステッブ数 $k$ が 1 でない場合は, まず式 (61) により直線 探索の収束判定を行う. 直線探索か叫束していない場合は, 式 (57) に従って設計変数を更新し, 直線探索を続ける.直 線探索が収束している場合は, 式 (62)により最急降下法の 収束判定を行う. 最急降下法が収束していない場合は, 式 (58)に従って設計変数を更新し, 新たな感度を求め, 直線 探索を行う，最急降下法が収束している場合は, 設計を終 了する．

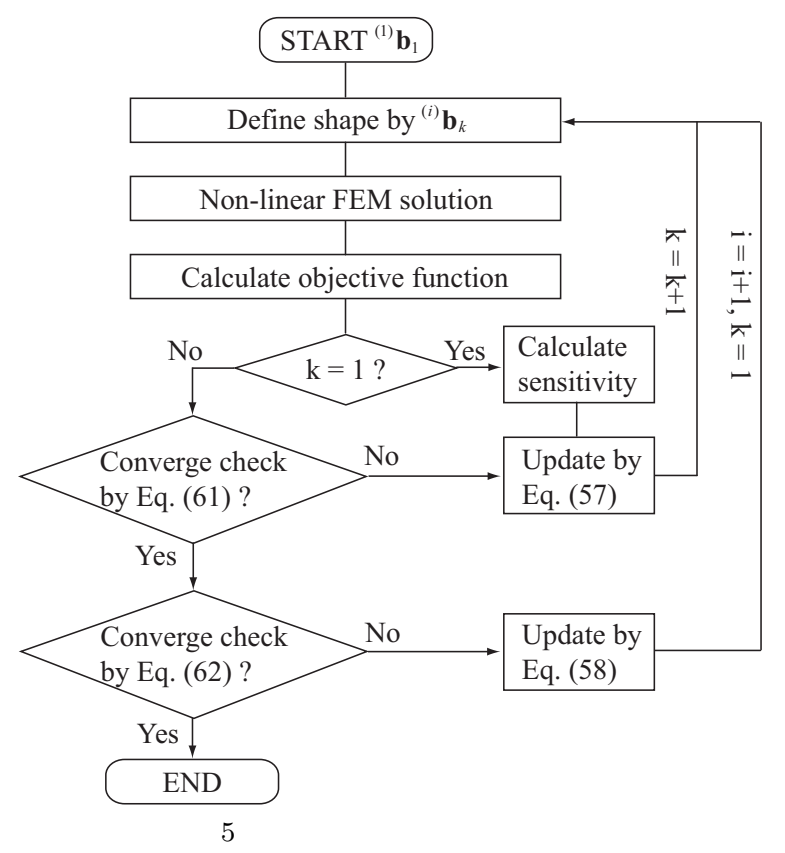

第 6 図に最急降下法の反復回数と, 目的関数, リンクル 量のみの目的関数, 及び面積との関係を示す.ただし，これ

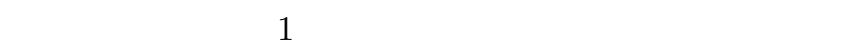
中で $\bar{\varphi}, \bar{U}_{w}, \bar{S}$ と記されている. 第 6 図からわかるように， 目的関数の值は, 反復回数が増加するごとに徐々に減少し， 一定値に近づいていることがわかる. 膜面全体のリンクル 量も同樣に, 反復回数の増加と共に隇少し, 収束点では初 期点の約 3 割程度までリンクル量が減少していることがわ かる. 一方, 膜面の面積は, 反復回数の増加と共に 0.9 に 近づいており，本例題て導入した面積の拘束を表すぺナル ティ関数が有効に作用していることがわかる. 第 7 図に設 計変数の值と各反復回数の関係を示す . ここで図中の設計 変数の值は, 初期状態を 1 として正規化されており, 正規 化された設計変数を $\bar{d}_{j}$ と記している. 图より反復回数の増 加と共に設計変数が一定值に収束する樣子がわかる. 第 8 図 (a) に, 反復回数が $i=1,8,10,21$ のときの膜面形状を 示す.ただし, 設計変数の値は表示のために, 初期值から の変化量を 2 倍にして表示している.図中の斜辺において， 実線が設計形状，鎖線が初期形状を表す.また第 8 図 (b) に, 各形状のリンクル量 $\phi_{w}$ の分布を示す. 第 8 図 (a)よ 


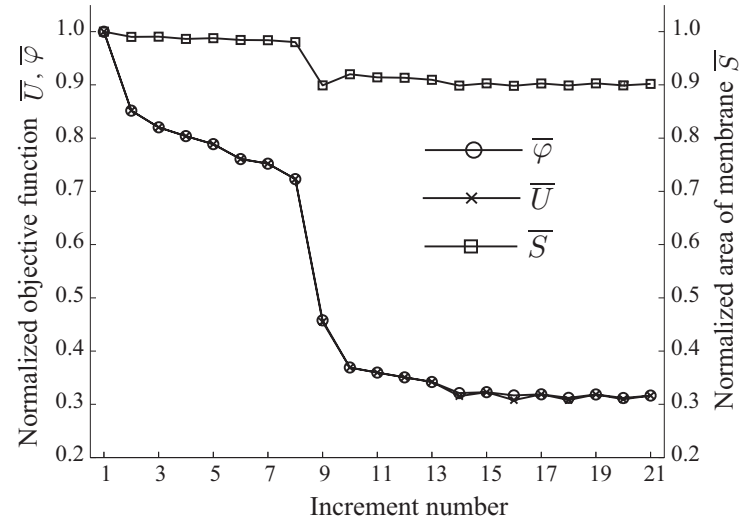

第 6 図 反復回数と評価関数の関係

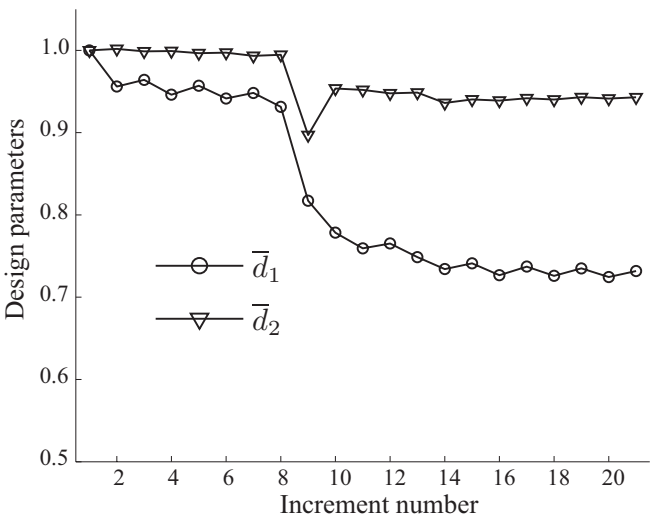

第 7 図 反復回数と設計変数の関係

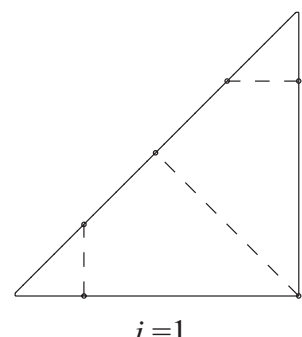

$i=1$

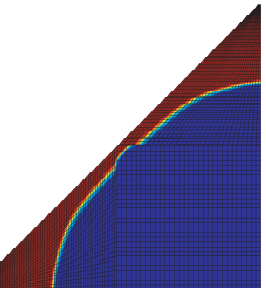

$i=1$

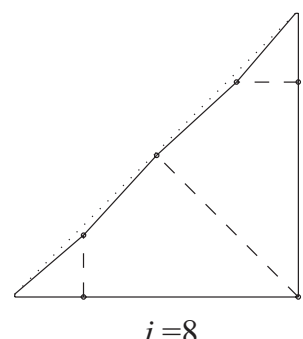

(a) Designed edge shapes

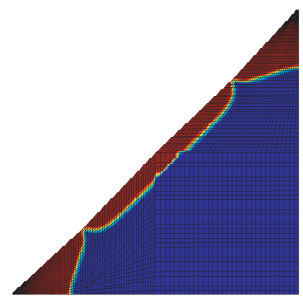

$i=8$

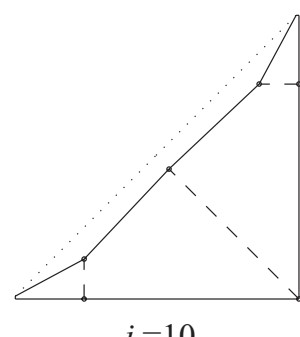

$i=10$

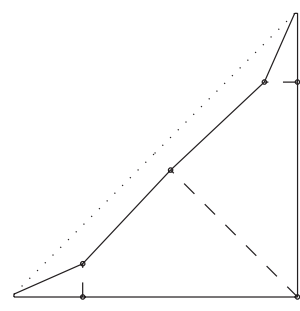

$i=21$

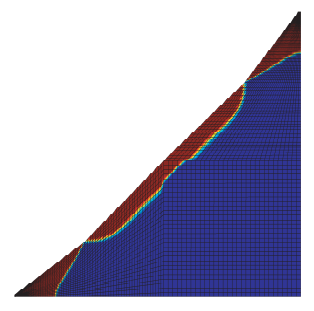

$i=10$

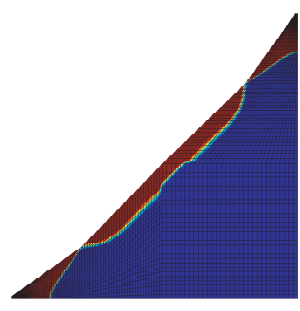

$i=21$

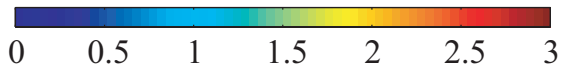

(b) Distributions of wrinkle quantities

第 8 図 膜面形状の設計結果

り, 反復回数が増加するごとに設計変数は長さの減少する 方向に変化し, 三角形の斜辺は内側にへこんだ状態に変化 することがわかる . また, 第 8 図 (b) のリンクル量 $\phi_{w}$ の 分布から, 反復の初期段階に, 鋭角の頂点と斜辺の周辺に 分布していたリンクルが, 反復を増すごとに大幅に減少し ていく樣子がわかる．以上の結果より，本論文で提案する リンクルに関する感度解析法が, リンクルの低減を目的と した形状設計問題に有効であることがわかる．

$$
\text { 5. ま と め }
$$

本論文では, 膜面のリンクルに関する評価関数を定義し， その感度評価式を求めた . また, 感度評価式を膜面のリン クルの減少を目的とした形状設計問題に適用し, 兴の有効 性を示した．本論文で求めた感度評価式は，任意の設計変 数に対するものであり，形状設計に限らず，樣々な構造設
計問題に適用可能である.

\section{参 考 文 献}

1）石原 競, 八木孝憲, 萩原伸幸, 大森博司：極小曲面解析による 膜構造の形状解析, 日本建築学会構造系論文集, 469 (1995), pp. 61-70.

2) Ishii, K.: Form Finding Analysis in Consideration of Cutting Patterns of Membrane Structures, International Journal of Space Structures, 14 (1999), pp. 105-119.

3) Fang, H. and Lou, M.: Catenary Systems for Membrane Structures, AIAA Paper 2001-1342, April, 2001.

4) Sakamoto, H., Park, K. C. and Miyazaki, Y.: Dynamic Wrinkle Reduction Strategies for Cable-Suspended Membrane Structures, Journal of Spacecraft and Rockets, 42 (2005), pp. $850-858$.

5) Murphey, T. W., Murphy D. M., Mikulas, M. M. and Adler, A. L.: A Method to Quantify the Thrust Degradation Effects of Structural Wrinkles in Solar Sails, AIAA Paper 2002-1560, April, 2002.

6) Johnston, J. D.: Finite Element Analysis of Wrinkled Mem- 
brane Structures for Sunshield Applications, AIAA Paper 2002-1456, April, 2002.

7) Mikulas, M. M. and Adler, A. L.: Rapid Structural Assessment Approach for Square Solar Sails Including Edge Support Cords, AIAA Paper 2003-1447, April, 2003.

8) Akita, T., Nakashino, K., Natori, M. C. and Park, K. C.: Derivation of Modified Stress-Strain Tensor for Wrinkled Membrane by Using Projection Matrix, Computational Mechanics WCCM VI in CD-ROM, 2004, Beijing, China.

9) Chen, X., Hisada, T., Kleiber, M. and Noguchi, H.: Comparison of different sensitivity analysis algorithms for large deformation elastic-plastic problems, Design-Sensitivity Analysis Atlanta Technology Publications, 1993. pp. 209-229.

10) Libai, A. and Simmonds, J. G.: The Nonlinear Theory of Elastic Shells (2nd edn.), Cambridge University Press, 1998. pp. 276-280, 431-441.

11) Moriya, K. and Uemura, M.: An Analysis of the Tension Field after Wrinkling in Flat Membrane Structure, Proceedings of 1971 IASS Pacific Symposium Part II on Tension Structures and Space Frames, 1972, pp. 189-198.

12）西村敏雄, 登坂宣好, 本間俊雄: 有限要素法による張力場解析手 法について, 日本建築学会構造系論文報告集, 368 (1985), pp. 27-35.

13) Miller, R. K., Hedgepeth, J. M., Weingarten, VI., Das, P. and Kahyai, S.: Finite Element Analysis of Partly Wrinkled Membranes, Computers and Structures, 20 (1985), pp. 631639.

14) Fujikake, M., Kojima, O. and Fukushima, S.: Analysis of Fabric Tension Structures, Computers and Structures, 32 (1989), pp. 537-547.

15) Miyazaki, Y. and Nakamura, Y.: Dynamic Analysis of Deployable Cable-Membrane Structures with Slackening Members, Proceedings of 21st International Symposium on Space Technology and Science, 1998, pp. 407-412.

16) Liu, X., Jenkins, C. H. and Shur, W. W.: Large Deflection Analysis of Pneumatic Envelopes Using a Penalty Parameter Modified Material Model, Finite Elements in Analysis and Design, 37 (2001), pp 233-251.

17) Ding, H. and Yang, B.: The Modeling and Numerical Analysis of Wrinkled Membranes, International Journal for $\mathrm{Nu}$ merical Methods in Engineering, 58 (2003), pp. 1785-1801.

18) $\mathrm{Wu}, \mathrm{C} . \mathrm{H}$. and Cansfield, T. R.: Wrinkling in Finite PlaneStress Theory, Quarterly of Applied Mathematics, 39 (1981), pp. 179-199.

19) Roddeman, D. G., Drukker, J., Oomens, C. W. and Janssen, J. D.: The Wrinkling of Thin Membranes: Part I - Theory, Journal of Applied Mechanics, 54 (1987), pp. 884-887.

20) Roddeman, D. G., Drukker, J., Oomens, C. W. and Janssen, J. D.: The Wrinkling of Thin Membranes: Part II - Numerical Analysis, Journal of Applied Mechanics, 54 (1987), pp. 888-892.

21) Roddeman, D. G.: Finite-Element Analysis of Wrinkling Membranes, Communications in Applied Numerical Meth- ods, 7 (1991), pp. 299-307.

22) Jeong, D. G. and Kwak, B. M.: Complementarity Problem Formulation for the Wrinkled Membrane and Numerical Implementation, Finite Elements in Analysis and Design, 12 (1992), pp. 91-104.

23) Muttin, F.: A Finite Element for Wrinkled Curved Elastic Membranes, and Its Application to Sail, Communications in Numerical Methods in Engineering, 12 (1996), pp. 775-785.

24) Kang, S. and Im, S.: Finite Element Analysis of Wrinkling Membranes, Journal of Applied Mechanics, 64 (1997), pp. 263-269.

25) Lu, K., Accorsi, M. and Leonard, J.: Finite Element Analysis of Membrane Wrinkling. International Journal for Numerical Methods in Engineering, 50 (2001), pp. 1017-1038.

26) Schoop, H., Taenzer, L. and Hornig, J.: Wrinkling of Nonlinear Membranes, Computational Mechanics, 29 (2002), pp. 68-74.

27）中篠恭一: 膜面やケーブルからなる構造物の解析法に関する研究, 東京大学博士論文, 2002 .

28) Nakashino, K. and Natori, M. C.: Efficient Modification Scheme of Stress-Strain Tensor for Wrinkled Membranes, AIAA Journal, 43 (2005), pp. 206-215.

29) Pipkin, A. C.: The Relaxed Energy Density for Isotropic Elastic Membranes, IMA Journal of Applied Mathematics, 36 (1986), pp. 85-99.

30) Pipkin, A. C.: Relaxed Energy Densities for Small Deformations of Membranes, IMA Journal of Applied Mathematics, 50 (1993), pp. 225-237.

31) Pipkin, A. C.: Relaxed Energy Densities for Large Deformations of Membranes, IMA Journal of Applied Mathematics, 52 (1994), pp. 297-308.

32) Steigmann, D. J. and Pipkin, A. C.: Finite Deformation of Wrinkled Membranes, Quarterly Journal of Mechanics and Applied Mathematics, 42 (1989), pp. 427-440.

33) Jenkins, C. H. and Leonard, J. W.: Dynamics Wrinkling of Viscoelastic Membranes, Journal of Applied Mechanics, 60 (1993), pp. 575-582.

34) Haseganu, E. and Steigmann, D. J.: Analysis of Partly Wrinkled Membranes by the Method of Dynamic Relaxation, Computational Mechanics, 14 (1994), pp. 596-614.

35) Epstein, M. and Forcinito, M.: Anisotropic Membrane Wrinkling: Theory and Analysis, International Journal of Solids and Structures, 38 (2001), pp. 5253-5272.

36) Miyazaki, Y.: Wrinkle/Slack Model and Finite Element Dynamics of Membrane, International Journal for Numerical Methods in Engineering, 66 (2006), pp. 1179-1209.

37) Blandino, J. R., Johnston, J. D. and Dharamsi, U. K.: Corner Wrinkling of a Square Membrane Due to Symmetric Mechanical Loads, Journal of Spacecraft and Rockets, 39 (2002), pp. 717-724.

38) 今野 浩, 山下 浩: 非線形計画法, 日科技連, 1978, pp.216-225. 